\title{
The Effect of Good Corporate Governance, Profitability, Capital Intensity and Company Size on Tax Avoidance
}

\author{
Sigit Widiatmoko, Hadri Mulya \\ Mercu Buana University, Indonesia \\ Mercu Buana University, Indonesia \\ Email: 5551711026@student.mercubuana.ac.id, hadri.mulya@mercubuana.ac.id
}

\begin{tabular}{|c|c|}
\hline ARTICLE INFO & ABSTRACT \\
\hline $\begin{array}{l}\text { Received } \\
23 \text { Juny } 2021 \\
\text { Revision } \\
1 \text { July } 2021 \\
\text { Approved } \\
10 \text { July } 2021\end{array}$ & \multirow{2}{*}{$\begin{array}{l}\text { This study aims to determine the effect of independent boardof } \\
\text { commissioners, institutional ownership, audit committee, profitability, } \\
\text { capital intensity, and to determine the effect of company size on tax } \\
\text { avoidance. So that the approach used in this research is a quantitative } \\
\text { approach with this type of approach, namely explanatory research. } \\
\text { The population in this study are all consumer goods companies that } \\
\text { have been listed on the Indonesia Stock Exchange (IDX) in 2015-2019 } \\
\text { as many as } 53 \text { companies. So that the sample used in this study is a } \\
\text { non-probability sampling method which is included in the purposive } \\
\text { sampling technique. This study produces an analysis which states that } \\
\text { the independent board of commissioners and institutional ownership } \\
\text { are declared to have no significant effect on Tax Avoidance in } \\
\text { consumer goods companies listed on the IDX from 2015-2019. As for } \\
\text { the audit committee, profitability, capital intensity, and also company } \\
\text { size have a significant effect on tax avoidance in consumer goods } \\
\text { companies that have been listed on the IDX for the 2015-2019 period. }\end{array}$} \\
\hline $\begin{array}{l}\text { Keywords: } \\
\text { board of } \\
\text { commissioners } \\
\text { institutional ownership } \\
\text { audit committee } \\
\text { profitability } \\
\text { capital intensity } \\
\text { company size and tax } \\
\text { avoidance }\end{array}$ & \\
\hline
\end{tabular}

\section{INTRODUCTION}

The definition of tax is a contribution of taxpayer to the government which must be paid to the country both individually and collectively along direct non-reciprocal, and the collection is regulated by constitution. On the other hand, most of the companies don't voluntary pay the tax because tax becomes company cost which can reduce net income. Due to that condition, many companies try to lower tax cost with a good way and don't against as a way to minimalize company loss with doing tax avoidance. So that tax avoidance's problem is a dilemmatic problem because on the one hand tax avoidance doesn't against the rule, but on the other hand tax avoidance is not in accordance with government's goal.
The realization of state revenue in the last three years from tax sector is stated cannot reach implemented target by APBN yet. The cause of an unachieved target is caused by level obedience of taxpayer which is still low. The low level of taxpayer obediencecaused by manytaxpayers who do not want to pay taxes and also there are taxpayers who make payments less than the regulation. So, it can be proved by Tax ratio which is only around $12.2 \%$, in $2019,11.6 \%$ in 2018 and $10.7 \%$ in 2017.

The factor which can give the impact of management in tax avoidance implementation, is corporate governance factor, profitability, capital intensity, and company size. This study has consumer goods companypopulation which has registered in Indonesia Stock Exchange (IDX)
How to cite:

E-ISSN:

Published by:
Widiatmoko, Sigit, Hadri Mulya (2021) The Effect of Good Corporate Governance, Profitability, Capital Intensity and Company Size on Tax Avoidance. Jurnal of Social Science 2(4). https://doi.org/10.46799/jss.v2i4.176 2721-5202

Ridwan Institute 
starts 2015-2019.The researchers choose consumer goods company as a subject of study, because considering work issuers of consumer goods sector in 2018-2019 which is positive valued. The Ministry of Trade records along 2018, consumers good industry is able to grow around $7.91 \%$ more than national economic growth at the percentage of $5.1 \%$.

\section{METHOD}

This study used quantitative approach by explanatory research type. Free variable which is used in this study is independent board commissionaire, institutional ownership, profitability, capital intensity and company size. Bound variable in this study is tax avoidance.

This study had population which was all consumer goods company which had been registered in Indonesia Stock Exchange (IDX) from 2015-2019 around 53 companies. In doing sample withdraw with non-probability sampling include purposive sampling technique. The secondary data is used in this study that gathered from annual report of Indonesia Stock Exchange. The taking data which was run with doing recording in each data used to make annual report in every company. So, data analyses used multiple linear regression with the help of SPSS application $24.00 \quad$ version.Descriptive statistical test and also classic assumptions was done first before doing multiple linear regression or hypothesis.

\section{RESULTS AND DISCUSSION}

From all total available company, there are 15 companies which fulfil stated sampling criteria. As for process of sample determination could be seen on table 1 .

Table 1

Process of Sampling Criteria

\begin{tabular}{clc}
\hline No. & \multicolumn{1}{c}{ Criteria of Sampling } & Amount \\
\hline 1 & $\begin{array}{l}\text { The amount of registered consumer } \\
\text { goods subsector company in Indonesia } \\
\text { Stock Exchange 2015-2019 period. }\end{array}$ & 53 \\
\hline $\begin{array}{l}\text { Consumer goods subsector company } \\
\text { which is not consistently publish } \\
\text { financial statements audit along 2015- } \\
2019 \text { period }\end{array}$ & $(17)$ \\
\hline 3 & $\begin{array}{l}\text { Consumer goods subsector company } \\
\text { which have loss along 2015-2019 } \\
\text { period }\end{array}$ & $(9)$ \\
\hline 4 & $\begin{array}{l}\text { Outlier data } \\
\text { The amount of company which was } \\
\text { made as sample }\end{array}$ & 15 \\
\hline The amount of sample (15 \\
companies* 5 years )
\end{tabular}

\section{A. Normality Test}

The testing of normality conduct by using kolmogorov and smirnov test to know whether the score distribution

normal or not. Kolmogrov-Smirnov, but if the value is higher $(>) 0,05$ so data can be said normal(Ghozali, 2013).

Table 2

Normality test One-Sample Kolmogorov-Smirnov

\begin{tabular}{ccc}
\hline & & $\begin{array}{r}\text { Unstandardized } \\
\text { Residual }\end{array}$ \\
\hline & $\mathrm{N}$ & 75 \\
\hline Normal & Mean &, 0000000 \\
\hline Parameters ${ }^{\mathrm{a}}, \mathrm{b}$ & Std.Deviation &, 04025015 \\
\hline Most Extreme & Absolute &, 076 \\
\cline { 2 - 3 } Differences & Positive &, 076 \\
\hline
\end{tabular}




\begin{tabular}{|c|c|}
\hline &,- 072 \\
\hline Test Statistic & ,076 \\
\hline $\begin{array}{l}\text { Asymp. Sig. (2- } \\
\text { tailed) }\end{array}$ & $200^{c, c}$ \\
\hline
\end{tabular}

The result of normality has the value of Asymp. Sig. (2-tailed) to unstandardized residual in the amount of 0.200 . This value is significant because bigger than 0.05 so it can be concluded that the data has been normal distributed.
Multicollinearity Test is aimed to be able to test on the regression model whether it is existing a correlation in independent variable. Regression model is said well if it has no correlation in independent variable(Ghozali, 2013).

\section{B. Multicollinearity Test}

Table 3

Multicollinearity Test Coefficients $q$

\begin{tabular}{ccc}
\hline \multirow{2}{*}{ Model } & \multicolumn{2}{c}{ Collinearity Statistics } \\
\cline { 2 - 3 } & Tolerance & VIF \\
\hline 1(Constant) & & \\
\hline Ind. Board Com &, 969 & 1,032 \\
\hline Ins. Own &, 370 & 2,704 \\
\hline Audit Com &, 686 & 1,457 \\
\hline ROA &, 604 & 1,657 \\
\hline Capital Int &, 417 & 2,396 \\
\hline Comp. Size &, 504 & 1,983 \\
\hline
\end{tabular}

Source: The result of data processing with SPSS 24 Version

From the result above, obtain tolerance value $>0.1$ and $\mathrm{VIF}<10$. The result is that each variable is not correlated one another or there is no problem multicollinearity from each variable.

\section{Heteroscedasticity Test}

Knowing the existence of heteroscedasticity can be done by doing
Glejser test. Glejser test can be used to regress between independent variable towards absolute value's residual (ABS_RES). If out of independent variableand also residual absolute has a significant value that is more than 0.05 so it can be said that there is no problem with heteroscedasticity.

Table 4

the result of Heteroscedasticity Test

Coefficients

\begin{tabular}{|c|c|c|c|c|c|c|}
\hline & \multirow{2}{*}{ Model } & \multicolumn{2}{|c|}{$\begin{array}{l}\text { Unstandardized } \\
\text { Coefficients }\end{array}$} & \multirow{2}{*}{$\begin{array}{c}\begin{array}{c}\text { Standardized } \\
\text { Coefficients }\end{array} \\
\text { Beta }\end{array}$} & \multirow{2}{*}{$\mathbf{t}$} & \multirow{2}{*}{ Sig } \\
\hline & & B & $\begin{array}{l}\text { Std. } \\
\text { Error }\end{array}$ & & & \\
\hline \multirow[t]{7}{*}{1} & (Constant) & ,139 & ,081 & & 1,723 & ,089 \\
\hline & Ind. Board Com &,- 026 & ,036 &,- 073 &,- 732 & ,467 \\
\hline & Ins. Own &, 017 & ,028 & ,099 &, 614 &, 541 \\
\hline & Audit Com &,- 015 & ,011 &,- 152 & $-1,282$ & ,204 \\
\hline & ROA &,- 178 & ,070 &,- 321 &,- 534 &, 214 \\
\hline & Capital Int &, 042 & ,028 &, 225 & 1,482 & , 143 \\
\hline & Comp. Size &,- 004 &, 002 &,- 258 & $-1,864$ & ,067 \\
\hline
\end{tabular}


Significant value on each independent variable (Independent board Commissioners, Institutional Ownership, Audit Committee, Profitability, Capital Intensity, and Company Size) gets bigger significant value than 0.05 . Therefore, it can be decided that if model has no problem of heteroscedasticity.

\section{Autocorrelation Test}

The test which isu sed to know the exist ence of auto correlation in this study is Durbin Watson test. The hypothesisi which will be testedis: $\mathrm{HO}$. Thereis no auto correlation $(r=0 ; \mathrm{Ha}$, the reisau to correlation $(r \neq 0)$.

Table5

The Result of Autocorrelation Test

\begin{tabular}{ccccccl}
\hline $\mathbf{N}$ & $\begin{array}{c}\text { DW } \\
\text { Count }\end{array}$ & 4-dU & 4-dL & $\begin{array}{c}\text { Table Dw } \\
\text { Lower limit } \\
\text { (dl) }\end{array}$ & $\begin{array}{c}\text { Table DW } \\
\text { Upper limit } \\
\text { (du) }\end{array}$ & Conclusion \\
\hline 75 & 1.791 & 2.199 & 2.542 & 1.458 & 1.801 & $\begin{array}{l}\text { There is no } \\
\text { negative or positive } \\
\text { autocorrelation }\end{array}$ \\
\hline
\end{tabular}

Source: the result of data processing using SPSS 24 Version

The result of autocorrelation test with Durbin-Watson can be detected if the value of DW-Count is around 1.791 so the value will be equalized with the value which is exist in the $5 \%$ alpha table, with the amount of sample (n) around 75 and the amount of independent variable around $6(k=6)$, so gets the value of Durbin Watson is $\mathrm{dL}=1.458$ and $\mathrm{du}=$ 1.801. On the value of Durbin-Watson around 1.791 so the conclusion if $\mathrm{du}<\mathrm{d}$ $<4$-du has the value $1.458<1.791<$ 2.199. So it can be said that if model has no negative or positive autocorrelation on regression model.

\section{E. Multiple Regression Analysis}

The Existence of multiple regression analysis has purpose to identify the existence of impact on independent variable, the existence of dependent variable which isconfirmed has ratio scale. In this study multiple linear regression analysis can be explained on the following table:

Table 6

Cronbach's Alpha from Research Model

\begin{tabular}{|c|c|c|c|c|c|c|}
\hline & \multirow[t]{2}{*}{ Model } & \multicolumn{2}{|c|}{$\begin{array}{l}\text { Unstandardized } \\
\text { Coefficients }\end{array}$} & \multirow{2}{*}{$\begin{array}{c}\text { Standardized } \\
\text { Coefficients } \\
\text { Beta }\end{array}$} & \multirow[t]{2}{*}{$\mathrm{t}$} & \multirow[t]{2}{*}{ Sig } \\
\hline & & B & $\begin{array}{l}\text { Std. } \\
\text { Error }\end{array}$ & & & \\
\hline \multirow[t]{7}{*}{1} & (Constant) & ,002 &, 149 & & ,012 & , 990 \\
\hline & Ind. Board Com &,- 067 & 066 &,- 099 & $-1,006$ & ,318 \\
\hline & Ins. Own & ,003 & 052 & ,009 & ,054 & ,957 \\
\hline & Audit Com & 057 & 021 & ,316 & 2,703 & ,009 \\
\hline & ROA &,- 445 & 129 &,- 428 & $-3,433$ & 001 \\
\hline & Capital Int &,- 119 & ,052 &,- 343 & $-2,285$ &, 025 \\
\hline & Comp. Size &, 013 & ,004 & ,412 & 3,019 & ,004 \\
\hline
\end{tabular}

Source: The result of data processing with SPSS 24 Version

$\mathrm{ETR}=0,002-0,067 \mathrm{KI}+0,003$ KEPINS + $0,057 \mathrm{KA}-0,445 \mathrm{ROA}-0,119 \mathrm{CIR}+0,013$ SIZE $+\mathrm{e}$

\section{F. Hypothesis TestDetermination} Coefficient Test

Determination Analysis $\left(R^{2}\right)$ has the purpose so that it can do measurement toward independent variable capability with describing dependent variable.If the value approaches 1 it means independent variable gives all the information needed to analyse dependent variable. The result of determination coefficient test in this study can be seen as follows: 
Table 6

Determination Coefficient Test ModelSummary

\begin{tabular}{ccccc}
\hline Model & $\mathbf{R}$ & $\begin{array}{c}\mathbf{R} \\
\text { Square }\end{array}$ & $\begin{array}{c}\text { Adjusted } \\
\mathbf{R} \text { Square }\end{array}$ & $\begin{array}{c}\text { Std. Error of } \\
\text { the Estimate }\end{array}$ \\
\hline 1 &, $601^{\text {a }}$ &, 361 &, 304 &, 041988 \\
\hline Source: & the result of data processing using SPSS 24 Version
\end{tabular}

Determination coefficient test showed $\mathrm{R}$ Square value in the amount of 0.361 so it can be said if independent variable is Independent board Commissioners, Institutional Ownership, Audit Committee, Profitability, Capital Intensity, and Company Size capable to explain Tax Avoidance's is in the amount of $36 \%$, while the residual is in the amount of $64 \%$ it was impact by another factor which is outside this model.

G. Hypothesis Test Results with F Test (Simultaneous Hypothesis)

This simultaneous test is used to know whether the independent variable (free) simultaneous gives significant effect on dependent variable (bound). The result of hypothesis test with $\mathrm{F}$ test is as follows:

Table 7

the Result of Simultaneous Hypothesis (F Test) ANOVA@

\begin{tabular}{|c|c|c|c|c|c|c|}
\hline & Model & $\begin{array}{l}\text { Sum of } \\
\text { Squares }\end{array}$ & df & $\begin{array}{l}\text { Mean } \\
\text { Square }\end{array}$ & $\mathbf{F}$ & Sig. \\
\hline \multirow[t]{3}{*}{1} & Regression & ,068 & 6 & ,011 & 6,394 &, $000^{\mathrm{b}}$ \\
\hline & Residual & 120 & 68 & ,002 & & \\
\hline & Total & 188 & 74 & & & \\
\hline
\end{tabular}

The table 7 shows that the result of simultaneously hypothesis test or $\mathrm{F}$ test produced significant value in the amount of $0.000<0.05$. So, the conclusion is Independent board Commissioners, Institutional Ownership, Audit Committee, Profitability, Capital Intensity, and Company Size all together is exist significant effect on Tax Avoidance in IDX registered Customer Goods company 2015-2019 period.

\section{H. Hypothesis Test Results with T Test (Partial Hypothesis)}

T statistic test basically described to what extent the impact of individually independent variable in describing the variety of dependent variable. If the significance probability value $<0.05$, it can be said that independent variable significant effect towards dependent variable.

Table 8

the Result of Partial Hypothesis Test Coefficients $^{\mathrm{a}}$

\begin{tabular}{cccc}
\hline & Model & t & Sig. \\
\hline 1 & (Constant) &, 012 &, 990 \\
\cline { 2 - 4 } & Ind. Board Com & $-1,006$ &, 318 \\
\hline Ins. Own &, 054 &, 957 \\
\hline Audit Com. & 2,703 &, 009 \\
\hline ROA & $-3,433$ &, 001 \\
\hline Capital Int. & $-2,285$ &, 025 \\
\hline Comp. Size & 3,019 &, 004 \\
\hline
\end{tabular}

Source: the result of data processingwith SPSS 24 Version

\section{First Hypothesis (H1)}

The variable of Independent Commissioners' gained negative beta value around 0.067 with $\mathrm{t}$-statistic value
$1.006<$ t-table value around $r 1.992$ and significance value $0.318>0.05$. So, Ho1 is received and $\mathrm{Ha} 1$ is rejected, so Independent commissioners did not give 
significant effect on tax avoidance in IDX registered consumers goods company period 2015-2019. This hypothesis supports the study by Marlinda, Dian Eva, Titisari, Kartika Hendra, \& Masitoh, Endang (2020) that is independent board commissioners does not give tax avoidance effect. Another study is from(Praditasari \& Setiawan, 2017)stated that independent commissioners does not give tax avoidanceeffect. Whereas in Triyanti, Novita Wahyu, Titisari, Kartika Hendra, \& Dewi, Riana Rachmawati. (2020) stated that independent commissioners do not give tax avoidance effect.

So that not all independent commissioners is able to state their independence. Therefore, independent board commissioners cannot avoid the existence of company which was doing tax avoidance.

\section{J. Second Hypothesis (H2)}

It can be seen that institutional ownership variable gained positive beta value in the amount of $r 0.003$ with the statistic around $0.054<\mathrm{t}$ table value around 1.992 and significance value $0.957>0.05$. So $\mathrm{Ho} 2$ is received and $\mathrm{Ha} 2$ is rejected, so institutional ownership variable does not give significant effect on tax avoidance in IDX registered consumer goods company period 2015-2019. The result of hypothesis is in accordance with the study of(Ulupui, 2016); (Jamei, 2017)stated that there is no significant effect between institutional ownership with tax avoidance. This showed that institutional ownership did not give significant effect on tax avoidance, it means institutional ownership's measurement did not make tax avoidance practiced by company can be avoided.

\section{K. Third Hypothesis (H3)}

The Audit Committee Variable gained positive beta value around 0.057 with t-statistic value in the amount of $2.703>$ t-table value around 1.992 and significant value $0.009<0.05$. Therefore, $\mathrm{Ho} 3$ is rejected and $\mathrm{Ha} 3$ is received, it can be concluded that if Audit Committee significant effect on tax avoidance in IDX registered consumer goods company period 2015-2019. This result of hypothesis supports Marlinda, Dian Eva,
Titisari, Kartika Hendra, \& Masitoh, Endang (2020) and(Ulupui, 2016)stated that audit committee gives impact on tax avoidance. The result of this study showed that the higher of the existence of audit committee in the company the better quality of corporate governance will be, so it can reduce possibility of the occurrence of tax avoidance activities. This result contradicted to(Alviyani, Surya, \& Rofika, 2016)audit committee does not give significant effect on tax avoidance which is done by the company.

\section{Fourth Hypothesis (H4)}

Profitability variable gained negative beta value around 0.445 with the $\mathrm{t}$ statistic value around $3.433>\mathrm{t}$-table value in the amount of 1.992 and significant value $0.001<0.05$. Therefore, $\mathrm{Ho} 4$ is rejected and $\mathrm{Ha} 4$ is received, it can be concluded that profitability variable significant effected on tax avoidance in IDX registered consumer goods company period 2015-2019. The result of hypothesis supported the study of(Maharani \& Suardana, 2014)which showed the result that profitability impacted negative on tax avoidance, the study stated that the company which makes a profit is assumed as not doing tax avoidance because it can manage its income and its tax payment. So, the higher profitability of the company the more press of tax avoidance action will be because highprofitability company tend to report their tax honestly from low profitability company.

\section{Fifth Hypothesis (H5)}

Capital Intensity variable gained negative beta value around 0.119 with the t-statistic value around $2.285<\mathrm{t}$-table value around 1.992 and significant value $0.0025<0.05$. Therefore, Ho5 is rejected and $\mathrm{Ha} \%$ is received, so it can be concluded that capital intensity variable proven significant effect on Tax Avoidance in IDX registered consumer goods company period 2015-2019. The result of study is in accordance with the study of(Dharma \& Noviari, 2017)modal intensity gives impact on tax avoidance. Modal intensity represents wealth owned by the company in the form of fixed asset investment. Almost all fixed asset will experience depreciation, with the 
existence of depreciation so company tax obligation will be low. This study is not in accordance with the study of(Marlinda, Titisari, \& Masitoh, 2020)which is modal intensity does not give impact of tax avoidance, it means company tend to invest their wealth in the form of fixed asset to support their operational activity.

\section{N. Sixth Hypothesis (H6)}

Company Size variable gained positive beta value around $0.013 \mathrm{t}$-statistic value around $3.019>t$-table value in the amount of 1.992 and significant value $0.004<0.05$. Therefore, Ho6 is rejected and $\mathrm{Ha} 6$ is received, so it can be concluded that company size variable significant effect on tax avoidance in IDX registered consumer goods company period 2015-2019.

The result of hypothesis supported the study of(Triyanti, Titisari, \& Dewi, 2020); (Irianto, Sudibyo, \& Wafirli, 2017);(Ulupui, 2016)that company size gives positive impact on tax avoidance. The bigger company asset the bigger company operational cost will be which is possible for the company to do more tax avoidance. The result of this study is not in accordance with the study of(Nugraheni \& Pratomo, 2018)company size does not give impact on tax avoidance. The bigger company the more control will be done by government towards that company. This control is done for reducing tax avoidance action which will be done by the company.

\section{CONCLUSION}

In accordance with the findings of the data analyssi above, it is concluded that the significance value of Independent Board Commissioners and Institutional Ownership has no significant effect on Tax Avoidance in IDX registered consumer goods company period 2015-2019.

Meanwhile, the factors that has impact on Tax Avoidance are Audit Committee, Profitability, Capital Intensity, and Company Size This study has consumer goods companypopulation which has registered in Indonesia Stock Exchange (IDX) starts 20152019.

\section{REFERENCES}

Alfina, I. T., Nurlaela, S., \& Wijayanti, A. (2018). The Influence of Profitability, Leverage, Independent Commissioner, and Company Size to Tax Avoidance. The 2nd International Conference on Technology, Education, and Social Science.Google Scholer

Armstrong, C. S., Blouin, J. L., Jagolinzer, A. D., \& Larcker, D. F. 2015. Corporate governance, incentives, and tax avoidance. Journal of Accounting and Economics, Vol.60, Issue1, Pp 1-17. Februari.Google Scholer

Arianandini, P. W., \& Ramantha, I. W. (2018). Pengaruh profitabilitas, leverage, dan kepemilikan institusional pada tax avoidance. E-Jurnal Akuntansi, Vol. 22, No. 3, pp. 2088-2116.Google Scholer

Ariawan, I. M. A. R., \& Setiawan, P. E. (2017). Pengaruh Dewan Komisaris Independen, Kepemilikan Institusional, Profitabilitas dan Leverge Terhadap Tax Avoidance. E-Jurnal Akuntansi, Vol. 18, No. 3, pp. 1831-1859.Google Scholer

Cahyono, D. D., Andini, R., \& Raharjo, K. (2016). Pengaruh komite audit, kepemilikan institusional, dewan komisaris, ukuran perusahaan (Size), leverage (DER) dan profitabilitas (ROA) terhadap tindakan penghindaran pajak (tax avoidance) pada perusahaan perbankan yang listing BEI periode tahun 2011-2013. Journal Of Accounting, Vol. 2, No. 2, pp. 110.Google Scholer

Charisma, R. B., \& Dwimulyani, S. (2019). Pengaruh Struktur Kepemilikan Terhadap Tindakan Penghindaran Pajak Dengan Kualitas Audit Sebagai Variabel Moderating. In Prosiding Seminar Nasional Pakar, pp. 232.Google Scholer

Dharma, N. B. S., \& Noviari, N. (2017). Pengaruh Corporate Social Responsibility dan Capital Intensity Terhadap Tax Avoidance. E-Jurnal 
Akuntansi, Vol. 18, No. 1, pp. 529556.Google Scholer

Diantari, P. R., \& Ulupui, I. A. (2016). Pengaruh komite audit, proporsi komisaris independen, dan proporsi kepemilikan institusional terhadap tax avoidance. E-Jurnal Akuntansi, Vol. 16, No. 1, pp. 702-732. Google Scholer

Direktorat Jenderal Pajak 2020, 'Laporan Kinerja (LAKIN) Direktorat Jenderal Pajak Tahun 2019'. Direktorat Jenderal Pajak, diakses 1 Agustus 2020, http://www.pajak.go.id .Google Scholer

Ghozali, I. (2013). Aplikasi Analisis Multivariate dengan Program IBM SPSS 21 Update PLS Regresi. Semarang: Badan Penerbit Universitas Diponegoro.Google Scholer

Irianto, B. S., Sudibyo, Y. A., \& Wafirli, A. (2017). The influence of profitability, leverage, firm size and capital intensity towards tax avoidance. International Journal of Accounting and Taxation, Vol. 5, No. 2, pp. 33-41.Google Scholer

Jamei, R. (2017). Tax Avoidance and Corporate Governance Mechanisms: Evidence from Tehran Stock Exchange. International Journal of Economics and Financial, Vol. 7, No. 4, pp. 638644.Google Scholer

Jensen, M. C., \& Meckling, W. H. (1986), Agency Cost of Free Cash Flow, Corporate Finance, and Takeovers,American Economic Review, Vol. 76, No. 2, pp. 323-329.Google scholer

Jessica, J., \& Toly, A. A. (2014). Pengaruh Pengungkapan Corporate Social Responsibilty Terhadap Agresivitas Pajak. Tax \& Accounting Review, Vol. 4, No. 1, pp. 1-16.Google Scholer

Kementrian Perindustrian 2020, 'Laporan Kinerja (LAKIN) Kementrian Perindustrian Tahun 2019'., diakses22 September 2020, http://www.kemenperin.go.id Google Scholer
Komite Nasional Kebijakan Governance (KNKG). 2006. Pedoman Umum GCG Indonesia, Jakarta.Google Scholer

Kuriah, H. L., \& Asyik, N. F. (2016). Pengaruh karakteristik perusahaan dan corporate social responsibility terhadap agresivitas pajak. Jurnal Ilmu dan Riset Akuntansi, Vol. 5, No. 3, pp. 119.Google Scholer

Kurniasih, T. \& Sari, M. M. R. (2013). Pengaruh Return on Assets, Leverage, Corporate Governance, ukuran perusahaan, dan kompensasi rugi fiscal pada tax avoidance.Buletin Studi Ekonomi, Vol. 18, No. 1, pp. 184.Google Scholer

Maharani, I. G. A. C., \& Suardana, K. A. (2014). Pengaruh Corporate Governance, Profitabilitas, dan Karakteristik Eksekutif pada Tax Avoidance Perusahaan Manufaktur. Ejurnal Akuntansi, Vol. 9, No. 2, pp. 525-539. Google Scholer

Marlinda, D. E., Titisari, K. H., \& Masitoh, E. (2020). Pengaruh Gcg, Profitabilitas, Capital Intensity, dan Ukuran Perusahaan terhadap Tax Avoidance. Ekonomis. Journal of Economics and Business, Vol. 4, No. 1, pp. 3947.Google Scholer

Moeljono, M. (2020). Faktor-Faktor yang Mempengaruhi Penghindaran Pajak. Jurnal Penelitan Ekonomi dan Bisnis, Vol. 5, No. 1, pp. 103-121.Google Scholer

Muzakki, M. R., \& Darsono, D. (2015). Pengaruh Corporate Social Responsibility dan capital intensity terhadap penghindaran pajak. Diponegoro Journal of Accounting, Vol. 4, No. 3, pp. 445-452.Google Scholer

Myers, S. C. (1977). Determinants of corporate borrowing. Journal of financial economics, Vol. 5, No. 2, pp. 147-175.Google Scholer 
Noor, R. M., Fadzillah, N. S. M., \& Mastuki, N. A. (2010). Corporate tax planning: a study on corporate effective tax rates of Malaysian listed companies. International Journal of Trade, Economics and Finance, Vol. 1, No. 2, pp. 189-193.Google Scholer

Olivia. V., Elisa. T. (2018) Role of Audit Committee in Tax Avoidance of Family and Non-Family Firms: Evidence from Indonesia.Journal of Economics and Business Vol.1, No.3, pp 368380.Google Scholer

Onyali., Innocent. C., Okafor., Gloria T (2018) Effect of Corporate Governance Mechanisms on TaxAggressiveness of Quoted Manufacturing Firms onthe Nigerian Stock Exchange. Asian Journal of Economics, Business and Accounting Vol. 8 No. 1 pp 1-20.Google Scholer

Pattiasina, V., Tammubua, MA., Numberi, A., Patiran, A.,Temalagi, S. (2019). Capital Intensity and Tax Avoidance:A Case in Indonesia. International Journal of Accounting And Taxation, Vol 5 No. 2, pp 58-71.Google Scholer

Peraturan Otoritas Jasa Keuangan Nomor 55/POJK.04/2015 tentang Pembentukan dan Pedoman Pelaksanaan Kerja Komite Audit.Google Scholer

Pitaloka, S., \& Merkusiawati, N. K. L. A. (2019). Pengaruh Profitabilitas, Leverage, Komite Audit, dan Karakter Eksekutif Terhadap Tax Avoidance. EJurnal Akuntansi, Vol. 27, No. 2, pp. 1202-1230. Google Scholer

Praditasari, A., \& Setiawan, P. E. (2017). Pengaruh Good Corporate Governance, Ukuran Perusahaan, Leverage dan Profitabilitas Pada Tax Avoidance. EJurnal Akuntansi, Vol. 19, No. 2, pp. 1229-1258.Google Scholer

Prakosa, K. B. (2014). Pengaruh Profitabilitas, Kepemilikan Keluarga dan Corporate Governance terhadap Penghindaran Pajak di Indonesia. Simposium Nasional Akuntansi 17.Google Scholer
Puspita, S. R., \& Harto, P. (2014). Pengaruh tata kelola perusahaan terhadap penghindaran pajak. Diponegoro Journal of Accounting, Vol. 3, No. 2, pp. 1077-1089.Google Scholer

Putra, I. G. L. N. D. C., \& Merkusiwati, N. K. L. A. (2016). Pengaruh Komisaris Independen , Leverage, Size dan Capital Intensity Ratio pada Tax Avoidance.E-Jurnal Akuntansi Universitas Udayana, Vol. 17, No. 1, pp. 690-714.Google Scholer

Putra, I. G. L. N. D. C., Sujana, I.K., Suprasto, H.B., Gayatri. (2019) Effect of Corporate Social Responsibility and Institutional Ownership of Tax Avoidance with Executive Characters as Moderator.International Research Journal of Management, IT \&Social Sciences Vol. 6, No. 6 pp 201206. Google Scholer

Richardson, G., \& Lanis, R. (2007). Determinants of the variability in corporate effective tax rates and tax reform: Evidence from Australia. Journal of accounting and public policy, Vol. 26, No. 6, pp. 689-704.Google Scholer

Richmadenda, R., \& Pratomo, D. (2018). Pengaruh Audit Tenur, Komite Audit dan Ukuran Perusahaan Terhadap Tax Avoidance. E-Proceedings of Management, Vol. 5, No. 3, pp. 33423349. Google Scholer

Rizal, M. ( 2016 ). Why Company Does Tax Avoidance?Evidence from a Manufacturing Company In Indonesia Stock Exchange. International Journal of Accounting And Taxation, Vol 5 No. 2 pp 63-70.Google Scholer

Fernández-Rodríguez, E., \& Martínez-Arias, A. (2012). Do business characteristics determine an effective tax rate? Evidence for listed companies in China and the United States. Chinese Economy, Vol. 45, No. 6, pp. 6083.Google Scholer 
Rozak, T. S., Hardiyanto, A. T., \& Fadillah, H. (2019). Pengaruh Profitabilitas, Likuiditas, Dan Leverage Terhadap Tax Avoidance. Jurnal Online Mahasiswa Bidang Akuntansi, Vol. 5, No. 5, pp. 120.Google Scholer

Sari, M., \& Devi, H. P. (2018). Pengaruh corporate governance dan profitabilitas terhadap tax avoidance. Jurnal Akuntansi, Vol. 2, No. 2, pp. 298306.Google Scholer

Siregar, S. (2013). Metode Penelitian Kuantitatif. Jakarta: PT Fajar Interpratama Mandiri.Google Scholer

Sugiyono. (2016). Metode Penelitian Kuantitatif, Kualitatif dan R\&D. Bandung: Alfabeta.Google Scholer
Tandean, V. A., \& Winnie, W. (2016). The effect of good corporate governance on tax avoidance: An empirical study on manufacturing companies listed in IDX period 2010-2013. Asian Journal of Accounting Research, Vol. 1, No. 1, pp. 28-38.Google Scholer

Waluyo, W. 2017. The Effect of Good Corporate Governance on Tax Avoidance:

Empirical Study of The Indonesian Banking Company. The Accounting Journal of Binaniaga. Vol. 2, Issue 02. Desember.Google Scholer

\section{Copyright holder:}

Sigit Widiatmoko, Hadri Mulya (2021)

First publication right:

Journal of Social Science

This article is licensed under:

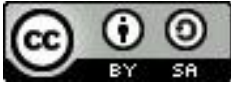

